\title{
THE NEXUS BETWEEN FISCAL DECENTRALIZATION AND GROSS INVESTMENT: A CASE STUDY OF PAKISTAN
}

\author{
Hamza*, Dr. Abdur Rauf $\dagger, \&$ Dr. Saleem Khan $\ddagger$
}

\begin{abstract}
Many countries around the globe attempted to decentralize the powers either political or financial to perform more efficiently. Pakistan being in search of growth also attempted to decentralize the financial authorities into lower tiers. Researchers empirically tested the various propositions of fiscal decentralization and this study is an addition in the literature while exploring the fiscal decentralization and gross investment nexus in case of Pakistan. The data period for underlying hypothesis ranged from 1985 to 2015. This study measured fiscal decentralization through fiscal transfers and the other control variables are, inflation and trade openness. The selected model is estimated by employing Autoregressive Distributive Lag Model (ARDL). Fiscal transfers although has positive sign but statistically it is insignificant which suggest that theoretically it attract investment but statistically these impacts are insignificant. Allocation of delegated fund into irrelevant projects and the attitude of political leaders to delegate/devolve the financial powers are the probable reasons for these results. Inflation discourage investment in this study sample period and trade openness attract investment. In light of the findings of this study it is suggested that the government may allocate the fund properly, control inflation and open the borders for trade to attract investment in Pakistan.
\end{abstract}

Keyword: Fiscal Decentralization, Investment, Inflation, ARDL.

\footnotetext{
BS Economics Student, Department of Economics, Abbottabad University of Science \& Technology (psmgreat34@gmail.com)

$\dagger$ Corresponding Author: Assistant Professor, Department of Economics, Abbottabad University of Science \& Technology (ab.rauf.khattak@gmail.com)

\# Assistant Professor, Department of Economics, Abdul Wali Khan University, Mardan (drsaleem.eco@awkum.edu.pk)
} 


\section{Introduction \\ Backgrounds}

Fiscal Decentralization is a process of devolution of fiscal powers from upper tiers to lower tiers in order to bring stability in the economy, enhance growth and helps in delivery of public services. Lower tiers are well informed of the needs of their locality and can help in better utilization of resources. Since the last two decades both developed and developing countries decentralize their economies to achieve the above objectives. Garman et al. (2001), analyzed 75 developing countries and found that amongst them morethan 80 percent nations gone through some decentralization of authority by the beginning of the millennium and same is the case in developed world too. Hooghe et al. (2010) develop an index for 42 nations called index of regional authority found that 70 percent of these countries decentralized.

Fiscal Decentralization can be good for both developed and developing countries if it is done properly. Generally developed economies have more potential to make fiscal decentralization beneficial as they have an established monitoring system. Likewise in Japan 2005, roughly 40 percent of total taxes were collected by local governments and afterward ratio of collecting taxes of central government in japan is relatively lower than local governments. Other than developed economies, the developing economies have different problems which are obstacles for fiscal decentralization to be beneficial for the economy. Like if we consider corruption as a problem which normally occurs in developing countries, if fiscal decentralization is set up in this problem having country than fiscal decentralization will be helpful to make corruption more easier rather than helpful for economic growth because in decentralized system more knowledge and more powers are delegated to the lower level institutions and hence bribery system can improve smoothly.

Decentralization in Pakistan is rooted since the British era. Afterward, these changes were done by three military administrations. In any case, it has been discovered that the devolutionary changes actualized by military administrations include exchanging of specific powers and capacities from provinces to neighborhood governments however regularly they fortify the local government. Since freedom, the Niemeyer Honor 1947, the Raisman Honor 1952, the One Unit Equation 1961 and 1965 and seven NFC grants in light of the 1973 Constitutions for income sharing have been declared. Constitution of Pakistan has attempted two noteworthy advancements by marking the seventh National Finance Commission (NFC) grant and by passing eighteenth Amendment (through which an extensive variety of monetary duties have been moved from the inside to the territories). These improvements would cause a principal move in the division of forces between the middle and the regions. This would have more self-rule in 
performing different capacities like the arrangement of macroeconomic administration.

The literature extensively investigated the growth and decentralization relationship. It is a multitasking phenomenon which gets the attention of several international agencies and the public sector authorities along with academia. All these try to pave the way for effective execution of decentralization of financial powers to enhance the deprived economies. Furthermore decentralization of financial authorities' role in promotion of public sector size with in transitional economies is a challenging job. This study tries to analyze this phenomenon by evaluating the relationship between fiscal decentralization and investment in case of Pakistan.

\section{Objectives of the Study}

Based on the above discussion the current is conducted to achieve the following objectives:

- To empirically tested the impacts of fiscal decentralization on investment in Pakistan

- To suggest a suitable policy for the government

\section{Hypotheses}

- $\mathrm{H}_{0}$ :Fiscal Decentralization has negative impacts on investment in Pakistan

- $\mathrm{H}_{\mathrm{A}}$ : Fiscal Decentralization has positive impacts on investment in Pakistan

\section{Structure of the Paper:}

Rest of the paper is as following; after the brief introduction next chapter highlighted some of the important previous studies on the said hypothesis, third chapter discussed methods of the study that is utilized in the conduction of this study. In fourth section the extracted results were discussed in detail and the final section five concluded the study along with policy implications.

\section{Literature Review}

Fiscal Decentralization has been analyzed by number of scholars. Most of the literature focus on fiscal decentralization and growth relationship and some of the scholars analyzed the decentralization relationship with other macroeconomics variables. The decentralization and investment relationship is very rarely investigated. The current study look at the existing literature into positive, negative and uncertain outcomes of fiscal decentralization along with the discussion of existing literature on fiscal decentralization and investment relationship. 


\section{Positive Impacts of Fiscal Decentralization}

Alderman (1998), directed his investigation for Albania and discovered encouraging effects of power delegation on communal help. Bardhan and Mookherjee (2003) directed their examination for India and said that power delegation supports in destitution allevation in India. Galasso and Ravallion (2001) said that delegation of power lessen destitution in Bangladesh. Habibi et. al. (2001) is of the view that financial delegation is useful for a superior conveyance of open administrations in Argentina. Eskeland and Filmer (2002) additionally found similar outcomes for Argentina. Faguet (2001) reasoned that if there should arise an occurrence of Bolivia regionalization helps in change of open administrations and causes the majority to get to social administrations all the more effectively. Isham and Kahkonen (1999) said that when the water services were overseen by nearby network it demonstrated enhancements. King and Ozler (1998) said that if there should arise an occurrence of Nicaragua the school administration at neighborhood level aided in score accomplishments. Estache and Sinha (1995) said that open foundation use expanded with devolution of power. Huther \& Shah (1998) and Enkolopov \& Zhuravskaya (2003) said that financial power delegation is useful in providing of open administrations all the more productively.

\section{Negative Impacts of Fiscal Decentralization}

Ravallion (1998) infer that if there would be an occurrence of Argentina, devolution of poweris a source of disparity and the deprived areas couldn't give open administrations proficiently. Azfar and Livingston (2002) for Uganda reasoned for adverse possessions of financial power delegation on the arrangement of open administrations. Correspondingly West and Wong (1995) additionally discovered lower tiers of conveyance of open administrations through devolution in the less created locales of China.

\section{Uncertain Impacts of Fiscal Decentralization}

Ahmad (2000) directed the investigation for Philippines and Uganda and found that the reaction of neighborhood constituencies is inadequate in light of the fact that these administrations have restricted specialist and are limited by a few requirements, e.g. confront procedural challenges; they have constrained wellsprings of financing and so forth. Khaleghian (2003) reasoned that monetary decentralization if there should arise an occurrence of center wage nations decrease the inclusion of inoculation. Winkler and Rounds (1996) said that devolution of training duties to the lower administration in spite of the fact that brought about proficiency help up however then again it lessens the score on subjective test. 


\section{Literature on Fiscal Decentralization and Investment Relationship}

This relationship is very rarely investigated. One can very hardly find few studies that examine this relationship e.g. Hanif and Chaudhry (2015) investigated fiscal decentralization and investment relationship in case of Pakistan and found that decentralization helps in attracting public investment in the economy. Same results were found by Chun and Sun (2018) for China.

The above discussed studies clearly suggest that there is no consensus amongst the researchers on the outcomes of fiscal decentralization. The existing literature varies from positive to negative and inconclusive findings. Investment and fiscal decentralization relationship is so far very rarely explored by the researcher. The current study will deviate from the existing literature on decentralization and investment relationship in terms of nature of analysis, i.e. the previous study conducted by Hanif and Chaudhry (2010) took public investment for the analysis while this study will take gross investment. Chun and Sun (2018) analysis was based on Panel data while this study take time series data for analysis. Furthermore, the previous studies used either revenue or expenditure side of fiscal decentralization or both but this study used intergovernmental fiscal transfers as measure of fiscal decentralization. World Bank $^{1}$ suggested various measures through which one can measure fiscal decentralization, i.e. Expenditure assignments, revenue assignments, Intergovernmental transfers and borrowing. The intergovernmental transfers, which we called fiscal transfers, are shift the revenues collected by federal/central government to local government for general and sometimes specific uses and one of the main source of revenue for lower tiers of governments.

\section{Data and Methodology}

\section{Data}

Time series data from 1985 to 2015 is collected for analyzing the research hypothesis. The State Bank of Pakistan (SBP) and various issues of Economic Survey of Pakistan are consulted to collect the data on selected variable. More specifically, the data on Gross investment (percentage of GDP), Fiscal transfers (percentage of GDP) and trade openness (export plus import divided by GDP) are taken from the various issues of economic survey of Pakistan and State Bank of Pakistan is consulted for the data of inflation (measured through GDP Deflator).

\footnotetext{
${ }^{1}$ http://www1.worldbank.org/publicsector/decentralization/fiscal.htm\#3
} 


\section{Methods}

\section{Empirical Model}

As stated earlier, gross investment, fiscal transfers, inflation and trade openness are the variables selected for the conduction of this study.

The functional form of the model is;

$$
G I N V=f(F T) \text {--------1 }
$$

GINV is gross investment in the above model and FT is fiscal transfers from central government to provincial government. These transfers are of great importance for lower governments as it is the main source of revenue for them therefore their designing has immense position for the efficient and equal distribution of resources and provision of services. World Bank provide five arguments for these transfers where each one can be applied to various degrees, i.e. fiscal gap, fiscal inequity, fiscal inefficiency, interstate spillover and fiscal harmonization. Transfers determined both as an objective and open, preferably through a given formula. Furthermore these are not hidden and decided by consensus (formula). In Pakistan National Finance Commission is set in 1974 to formulate a specific formula for that purpose. This commission set after every five years to redistribute the resources/revenue from the divisible pool amongst the different provinces of Pakistan. On the basis of the assumptions associated with the outcome of fiscal decentralization, the current study further assume that it will attract investment too along with growth enhancement, bring stability and helps in delivery of public services.

By including the control variables in our first equation, it will become,

$$
G I N V=f(F T, Z) \text {----------2 }
$$

The control variables ( $\mathrm{Z}$ in our model) are inflation and trade openness. Inflation is a great threat to investment and has two folded effects on investment, one, inflation increase the cost of production and thus the product become costly and thus hinders the economic activity and second because it affect the purchasing power and blemish the savings returns. Thus it become difficult for a buyer to buy the product and economic activity shrink. Trade openness is another control variable in our model. It is assumed that trade liberalization has manifold benefits for the economy. It helps in technological transfers, helps in skills transfers and increase productivity. With liberalization of trade new markets explored for domestic firms and brings innovations through competitions. Pakistan being a trade liberalized country, it is assumed that trade openness in our case will have positive impacts on investment.

Specific econometric model is as following;

$$
G I N V_{t}=\alpha+\beta\left(F T_{t}\right)+\delta\left(Z_{t}\right)+\varepsilon_{t}------------3
$$


Epsilon ( $\varepsilon$ ) is error term, $\alpha, \beta$ and $\delta$ are the constant and subscript " $t$ " is time factor. Rest of the notations are explained previously.

\section{Estimation Strategy}

Autoregressive Distributive lag model (ARDL) is used for empirical analysis. This specific test is selected because of the following reasons; efficient even the data is for shorter period, Applicable irrespective of the fact that there is mix order of integration. At three different stages the application of ARDL is completed, where first the long run cointegration is analyzed, once the cointegration is established, in a second stage the long run elasticities are extracted and in a third and final stage the short run effects are find out, (See Pesaran et al (2001))

Our model is as following;

Stage 1. For Long Run Cointegration Analysis

$$
\begin{aligned}
\Delta G I N V=\alpha 0+ & \sum_{i=1}^{l} \varphi 1 \Delta G I N V t-i+\sum_{j=1}^{m} \varphi 2 \Delta F T t-j+\sum_{k=1}^{n} \varphi 3 \Delta I N F t-k+\sum_{m=1}^{p} \varphi 4 \Delta T O t \\
& -m++\beta 1 \text { GINVt }-1+\beta 2 F T t-1+\beta 3 \text { INFt }-1++\beta 4 T O t-1 \varepsilon t \ldots . .1
\end{aligned}
$$

Where the GINV stands for Gross National Product FT is fiscal transfers, INF is inflation and TO stands for Trade Openness.

Stage 2. For Long Run Estimates:

GINVt $=\alpha 0+\beta 1$ GINVt $-1+\beta 2 F T t-1+\beta 3 I N F t-1+\beta 4 T O t-1+\varepsilon t \ldots . . .2$

Stage 3. For Short Run Estimates:

$$
\begin{gathered}
\Delta G I N V t=\alpha 0+\sum_{i=1}^{l} \varphi 1 \Delta G I N V t-i+\sum_{j=1}^{m} \varphi 2 \Delta F T t-j+\sum_{k=1}^{n} \varphi 3 \Delta I N F t-k \\
++\sum_{m=1}^{p} \varphi 4 \Delta T O t-m+\text { vecm }-1+\varepsilon t \ldots .3
\end{gathered}
$$

\section{Results and Discussion}

\section{Unit Root Analysis}

To avoid spurious regression, one has to test the time series data for unit root. For this purpose, this study used Augmented Dicky Fuller test. As clear from the table 1 below, the stationarity analysis is made with intercept and then with trend and intercept. The results depicted in table 1 suggest that all the variables are stationary at level except inflation which is integrated at order one thus it is concluded that we have mix order of integration. The results are displayed below; 
Table 1: Unit Root Analysis

\begin{tabular}{|l|c|c|c|c|}
\hline Variables & \multicolumn{2}{|c|}{ Level } & \multicolumn{2}{c|}{$\mathbf{1}^{\text {st }}$ Difference } \\
\hline & Intercept & T + I & Intercept & T+I \\
\hline FT & -4.6756 & -5.1297 & ------ & ---- \\
& $(0.0008)$ & $(0.0013)$ & & \\
\hline GINV & -5.1818 & -5.5336 & ------ & ------- \\
& $(0.0002)$ & $(0.0005)$ & & \\
\hline INF & -2.3500 & -2.1686 & -6.4436 & -6.5583 \\
& $(0.1639)$ & $(0.4889)$ & $(0.000)$ & $(0.000)$ \\
\hline TO & -5.4045 & -5.3510 & ----- & ----- \\
& $(0.0001)$ & $(0.0008)$ & & \\
\hline
\end{tabular}

Author's Calculation.

\section{Correlation Matrix}

Correlation matrix summarize the data as an input to more advanced analysis by showing correlation coefficients between random variables. The table 2 which has the results of correlation matrix shows that there is no perfect collinearity between the variables selected for the analysis of this hypothesis. The results are displayed in table 2 below.

Table 2: Correlation Matrix

\begin{tabular}{|l|c|c|c|c|}
\hline & TO & INF & GINV & FT \\
\hline TO & 1.000 & 0.124815 & 0.923190 & 0.888074 \\
\hline INF & 0.124815 & 1.000 & 0.140555 & 0.114056 \\
\hline GINV & 0.923190 & 0.140555 & 1.000 & 0.979692 \\
\hline FT & 0.888074 & 0.114056 & 0.979692 & 1.000 \\
\hline
\end{tabular}

Author's Calculation.

\section{Lag Length and Criteria Selection}

Table below present the lag length selection criteria for the analysis. The results presented in table 3 suggest that Akaike Information Criteria at lag one is the best criteria for our analysis.

\section{Table 3: Lag Length Selection Criteria}

\begin{tabular}{|c|c|c|c|c|c|c|}
\hline Lag & LogL & LR & FPE & AIC & SC & HQ \\
\hline $\mathbf{0}$ & -338.8298 & NA & 217952.7 & 23.64343 & 23.83202 & 23.70250 \\
\hline $\mathbf{1}$ & -232.0017 & 17.21153 & 1361.070 & $18.48288^{*}$ & 20.18021 & 19.01446 \\
\hline $\mathbf{2}$ & -244.4801 & 156.1650 & 994.6731 & 18.54001 & 19.18297 & 18.53533 \\
\hline
\end{tabular}

* indicates lag order selected by the criterion 


\section{Long Run Cointegration Analysis}

In the first stage of ARDL as discussed above we have to find out the long run cointegration analysis. In case of our model there exist long run cointegration as the critical value of Wald $\mathrm{F}$ exceeds the upper bound at 5\% level of significance, (See table 4 below for detail)

\section{Table 4: The Bound Test for Co-integration}

\begin{tabular}{|l|c|c|c|c|}
\hline Model Specification & LB & UB & F-statistic & Decision \\
\hline GINV/FT,TO,INF & 5.856 & 7.578 & 8.980 & $\begin{array}{c}\text { Co } \\
\text { integration }\end{array}$ \\
\hline
\end{tabular}

LB: Lower Bound, UB Upper Bound

\section{Long Run Estimates}

The results presented in table 5 shows that although there exist positive but statistically insignificant relationship between Fiscal Decentralization and Gross Investment, which mean that Fiscal Decentralization don not attract investment in Pakistan. The possible reasons behind this insignificant result are mismanagement/improper allocated of funds, investment policies formulated by the government, attitude of the political leaders towards decentralization and most importantly the fallacies in transfer system. Therefore a system of transfers has to be which can improve the efficiency and productivity through competitions and the masses has to be involved in decision making so that the funds can be allocated properly and meaningfully. Talking about other variables, inflation has negative impact on investments. It reduce investment by $8 \%$ with one degree increase in inflation. These results are quite understandable as inflation reduce the purchasing power of savings, overtake interest rates and has great impact on stock market returns. Whereas trade openness has significant positive impacts on investment in Pakistan that suggest that with trade liberalization investment will increase in Pakistan.

Table 5: Long Run Estimates

\begin{tabular}{|l|c|c|c|c|}
\hline Regressors & Coefficient & Standard Error & T-Ratio & {$[$ Prob] } \\
\hline INF & -0.087470 & 0.049206 & -1.7776 & {$[0.089]$} \\
\hline FT & 0.30757 & 0.34658 & 0.88745 & {$[0.384]$} \\
\hline TO & 0.18100 & 0.018886 & 9.5836 & {$[0.000]$} \\
\hline A & -3.5135 & 0.80132 & -4.3846 & {$[0.000]$} \\
\hline T & 0.44861 & 0.055168 & 8.1316 & {$[0.000]$} \\
\hline R $^{2}=0.70$ & Adj.R ${ }^{2}=0.62$ & & & \\
\hline D.W. $=1.81$ & F-Stat. & $7.69(0.00)$ & & \\
\hline
\end{tabular}




\section{Short Run Estimates}

The results of short run are much similar to the long run estimates. Coefficient of ECM shows that speed of adjustment is $62 \%$. Values of Fstatistics show that explanatory variables are important determinants of gross investment in Pakistan. Value of R-Squared shows that most of the variations are explained by the explanatory variables.

Table 6: Short Run Estimates

\begin{tabular}{|l|c|c|c|c|}
\hline Regressors & Coefficient & $\begin{array}{c}\text { Standard } \\
\text { Error }\end{array}$ & T-Ratio & [Prob] \\
\hline dINF & -0.055032 & 0.029505 & -1.8651 & {$[0.075]$} \\
\hline dFT & -0.19351 & 0.22037 & -0.87811 & {$[0.389]$} \\
\hline dTO & 0.17715 & 0.011481 & 15.4294 & {$[0.000]$} \\
\hline dA & -2.2105 & 0.86326 & -2.5606 & {$[0.017$} \\
\hline dT & 0.28224 & 0.080535 & 3.5046 & {$[0.002]$} \\
\hline ecm(-1) & -0.62915 & 0.17590 & -3.5767 & {$[0.002]$} \\
\hline R $^{2}=0.99$ & Adj.R ${ }^{2}=$ & & & \\
\hline $\begin{array}{l}\text { D.W. } \\
1.81\end{array}$ & F-Stat. & $9.38(0.00)$ & & \\
\hline
\end{tabular}

\section{Diagnostic Test:}

The results displayed in table 7 below suggest that our model is free from serial correlation and heteroscadasticity. Furthermore the diagnostic tests evident that the functional form of the model is correct and the errors are normally distributed.

Table 7: Diagnostic Test

\begin{tabular}{|l|c|c|}
\hline Test Statistics & LM Version & F Version \\
\hline A: Serial Correlation & CHSQ $=0.53817$ & $\mathrm{~F}(1,21)=0.39708$ \\
& {$[0.463]$} & {$[0.535]$} \\
\hline B: Functional Form & $\mathrm{CHSQ}=3.9682$ & $\mathrm{~F}(1,21)=3.3290$ \\
& {$[0.046]$} & {$[0.082]$} \\
\hline C: Normality & $\mathrm{CHSQ}=3.6440$ & Not Applicable \\
& {$[0.162]$} & $\mathrm{F}(1,27)=0.15812$ \\
\hline D: & $\mathrm{CHSQ}=0.16884$ & {$[0.694]$} \\
Heteroskedasticity & {$[0.681]$} & \multicolumn{2}{|c|}{} \\
\hline
\end{tabular}

Author's calculation 


\section{Stability Test}

CUSUM and COSUMQ are used to check the stability of our model. It is clear from the figure below that our model is stable in the selected time frame.

\section{Plot of Cumulative Sum of Recursive Residuals}

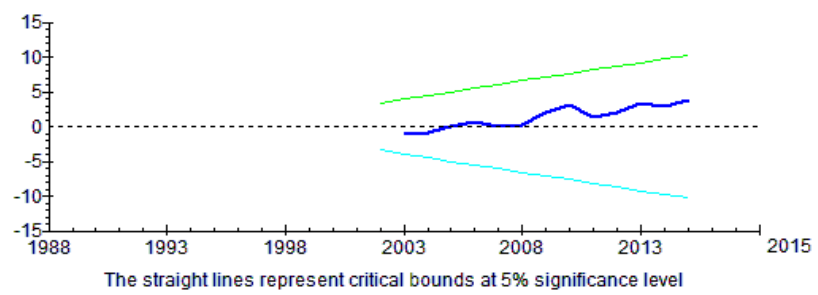

Plot of Cumulative Sum of Squares of Recursive Residuals

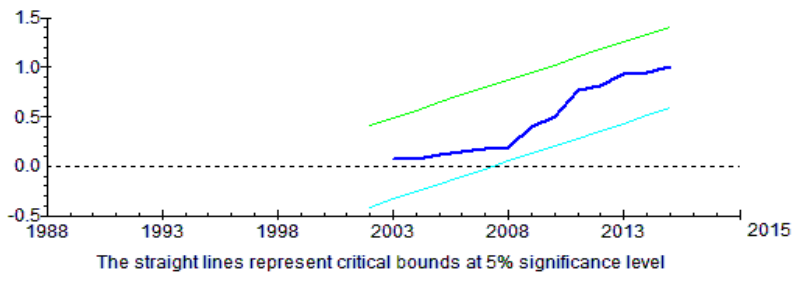

Fig. 1: CUSUM and COSUMQ

\section{Conclusion}

Devolution of financial powers is one of the important module of decentralization. This decentralization of financial powers are assumed to help in many folds, i. improve growth ii. Helps in better delivery of public services and iii. Bring economic stability in the economy. This study assumed that if decentralization of financial powers has manifold advantages for the economy then it might be helpful for attracting the investment too. Therefore, this study focused on the analysis of the impacts of Fiscal Decentralization on Gross Investment. The study took Pakistan as a case study. The sample period selected from 1985 to 2015. The existence of long run cointegration is analyzed through Wald $\mathrm{F}$ statistics. The long run estimates are extracted through the ARDL and short run dynamics and speed of adjustment were found out by ECM. Furthermore, to check the stability of coefficients, CUSUM and CUSUMQ were employed. The results of Wald F-Statistics suggested that there exist long run cointegration in the model as 
the calculated Wald F value (8.98) is higher than the upper bounds of the tabulated Wald F-value (7.57) at 5\% level of significance. The results of the estimated model suggested that theoretically fiscal decentralization helps in bringing investment in the economy but statistically these impacts are irrelevant or insignificant. On the other hand inflation used as a control variable has negative impacts on investment and trade openness attract investment in Pakistan. ECM affirmed the long run relationship and a sensible speed that correct the disequilibria in a year. The coefficient of determination suggested that $70 \%$ variations in dependent variable were explained by the explanatory variables. Various diagnostic tests were applied to check the model for serial correlation, heteroscadasticity, functional form of the selected model and the normality of the model. The results suggested that the selected model is free from all the above. The CUSUM and CUSUMQ displayed the coefficients stability and as the coefficients are inside of the bounds therefore it shows stable pattern over the sample period.

\section{Recommendations}

On the basis of the findings of this study it is recommended that

- The government may make it sure that the delegated fund is used in allocated projects, the masses has to be involved in the decision making and this will help in building of trust of the investors and investment will be attracted in the economy.

- The inflation control policies will help in reducing the cost of production and will have less effect on the purchasing power which will encourage the investors to invest in the economy as decrease in cost of production accompanied by increase in purchasing power of consumer will boost economic activity and thus encourage investors.

- To increase investment in the country, the government may bring more reforms in trade liberalization so that a country become prosperous.

\section{References}

Ahmad, M.E. (2000).“On the implementation of transfers to subnational governments.” IMF Working Paper 05/130. Washington, DC: International Monetary Fund.

Alderman, H. (1998). "Social Assistance in Albania: Decentralization and Targeted Transfers". LSMS Working Paper no. 134. World Bank, Washington D.C.

Azfar, O. \& J. Livingston (2002). "Federalist Disciplines or Local Capture? An Empirical Analysis of Decentralization in Uganda." IRIS, University of Maryland. 
Bardhan, P. \& D. Mookherjee (2003). "Poverty Alleviation Effort of West Bengal

Panchayats".http://econ.bu.edu/dilipm/wkpap.htm/epwsumm.pdf

Dickey, D.A. \& W.A. Fuller (1981). "Likelihood ratio statistics for autoregressive time series with a unit root". Econometrica.49. 10571079.

Enikolopov, R. \& E. Zhuravskaya (2003). "Decentralization and Political Institutions."

http://emlab.berkeley.edu/users/webfac/bardhan/e271_f03/oct6.pdf

Eskeland, G. \& D. Filmer (2002). "Autonomy, Participation, and Learning in Argentine Schools: Findings and Their Implications for Decentralization." Policy Research Working Paper 2766. World Bank,Washington DC.

Estache, A. \& S. Sinha (1995). "Does Decentralization Increase Spending on Public Infrastructure?" The World Bank Policy Research Working Paper 1457.

Faguet, J. \& Paul G. (2001). "Does Decentralization Increase Government Responsiveness to Local Needs? Evidence from Bolivia”, World Bank Policy Research Working Paper No. 2516.

Faguet, J.P. (2001). "Does Decentralization Increase Responsiveness to Local Needs? Evidence from Bolivia." Policy Research Working Paper \#2516. World Bank. Washington DC.

Galasso, E. \& M. Ravallion (1998). "Reaching Poor Areas in a Federal System." Policy Research Working Paper \#1901.World Bank, Washington DC.

Garman, C. Haggard, S. \& Willis, E. (2001). "Fiscal Decentralization: A political theory with Latin American cases. 'World Politics.53 (2). 205236.

Government of Pakistan. Various issues of Economic Survey of Pakistan. http://www.finance.gov.pk/

He, Q. \& Sun, M. (2018). "Does Fiscal Decentralization Increase Investment Rate? Evidence from Chinese Panel Data." Annals of Economics and Finance. 19(1). 75-101.

Habibi, N., C. Huang, D. Miranda, V. Murillo, G. Ranis, M. Sarkar, \& F. Stewart (2001). "Decentralization in Argentina." Economic Growth Center Discussion Paper 825. Yale University.

Hanif, I. \& Chaudhry, S.I. (2015). "Interlinks of Fiscal Decentralization and Public Investment in Pakistan." Pakistan journal of Commerce and Social Sciences. 9(3). 850-864.

Hooghe, L., Marks, G., Schakel, A.H., Chapman, S., Niedzwiecki, S. \& Shair-Rosenfield, S. (2016). A Postfunctionalist Theory of Governance. Volume I: Measuring RegionalAuthority. Oxford: Oxford University Press. 
Huther, J. \& A. Shah (1998). "Applying a Simple Measure of Good Governance to the Debate on Fiscal Decentralization." Policy Research Working Paper Number 1894.World Bank. Washington, DC.

Isham, J. \& S. Kähkönen (1999). "What Determines the Effectiveness of Community-based Water Projects? Evidence from Central Java, Indonesia on Demand Responsiveness, Service Rules, and Social Capital." University of Maryland.

Khaleghian, P. (2003). "Decentralization and Public Services: The Case of Immunization." Policy Research Working Paper 2989.World Bank. Washington, DC.

King, E. \& B. Ozler (1998). "What's Decentralization Got To Do With Learning? The Case of Nicaragua's School Autonomy Reform. Development," Research Group Working Paper, World Bank. Washington D.C.

Pesaran, M.H., Shin, Y. \& R.J. Smith (2001). "Bounds testing approaches to the analysis of long run relationships", Journal of Applied Econometrics, 16, 289-326.

Pesaran, M.H. \& Shin, Y. (1999). "An autoregressive distributed-led modeling approach to cointegration analysis." In Econometrics and Economic Theory in the 20th Century. The Ragnar Frisch Centennial Symposium, ed. Steinar Strom. Cambridge: Cambridge University Press.

Pakistan. Finance Division, Economic Advisor's Wing: Economic Survey various Issues. http://www.finance.gov.pk.

West, L. \& C. Wong (1995). "Fiscal Decentralization and Growth Regional Disparities in Rural China: Some Evidence in the Provision of Social Services." Oxford Review of Economic Policy. 11(4): 70 - 84.

State Bank of Pakistan. http://www.sbp.org.pk/

Winkler, D. \& T. Rounds (1996). "Municipal and Private Sector Response to Decentralization and School Choice." Economics of Education Review. 15 (4): 365-376.

World Bank. https://data.worldbank.org/ 